\title{
THE TEACHER'S PERCEPTION TO THE IMPACT OF PLAYING GADGET FOR EARly ChILdHOOd's MENTAL HEALTH
}

\author{
Desni Yuniarni \\ Universitas Tanjungpura, Pontianak, Indonesia \\ E-mail:desni.yuniarni@fkip.untan.ac.id
}

\begin{abstract}
Playing games using gadgets in early childhood is now a common thing. Children mostly spend their time playing gadgets alone rather than playing with their friends. This has an impact on their mental development, especially their social and emotional development. Unfortunately, it has not become a concern for the parents. They assume that playing gadget would not affect their children's mental development at all. Therefore, this study aims to find out how is the teacher's perception of playing gadgets for early childhood mental health, especially in their social and emotional aspects. This was a qualitative study, in the form of a case study. Data were obtained through interviews and focused group discussions by 7 kindergarten teachers from 4 different classes. The study result reveals that all the teachers had the same perceptive that gadget has both positive and negative effects on early childhood's mental health. The positive impact of the gadget for early childhood's mental health is the contains of the games can stimulate the creativity and imagination for the children. Besides, the games in the gadget should be educative so they can learn in a fun way. The positive emotion of children when learning using gadgets will also maintain their mental health. The negative impact of the gadget for early childhood's mental health is if there they become addicted to the gadget so they spend more time playing gadget and refuse to interact with other people. As an effect, they will face difficulty in communicate with other people, get angry easily, hard to concentrate, unruly, which such things may cause deterioration in their mental health. Finally, teachers and parents as a significant person for the children must control the children while playing gadgets and give the rules and boundaries for the children to maintain their children's mental health.
\end{abstract}

Keywords: Early Childhood; Mental Health; Playing Gadget; Teacher's Perception

\section{INTRODUCTION}

A child with good mental health is a happy child. He can adapt well in his environment, is not afraid to express $\mathrm{him} /$ herself, cheerful, full of creativity, imaginative, dare to try new things, and want to learn to adapt to people in the nearby environment. Children develop their social skills and express their emotions in a way that is acceptable to the environment. All those skills are learned by children if they get the chance to directly interact with their environment. This argument is in line with the experts' opinions who stated that the development of emotional and social skills are the important skills that need to be learned by children aged 0-5 years so that they can interact with other people, to get experience, learn the rules, and learn to express their emotion in a way that is acceptable to their environment, both in family, social, and cultural environments (Yates et al., 2008).

According to Hartati (2007: 10), early childhood is a group of individuals in the age range of 0-8 years. Karman
(2013) stated that children aged 6 years and under have been involved in the use of new media and technology since they were born. As a result, it can be concluded that early childhood, those in the age range of 0-8 years, is now involved in the use of technology, especially gadgets.

According to Widiawati and Sugiman (2014) gadgets are small objects (tools or electronic items) that have special functions, but are often associated as an innovation or new item. Children will face obstacles in their social and emotional development if they have less opportunity to directly interact with their surroundings. Rahman (2009) stated that the lack of stimulation provided by parents and the surrounding environment can be a cause of problems in a child's psychosocial development at preschool ages. Laili (2017) said that problems arise lately is because of the assumptions of parents who think that by giving their children gadgets, they will be more focused on their gadgets so parents can be more concentrated in doing their work. This becomes one of the reasons why parents in Indonesia still give gadgets to their children who are still young. 
Besides, the use of gadgets among children in Indonesia is now a common thing and the fact is, Indonesia is one of the biggest gadget users in the world (Indrawan, 2004).

Gadgets are a small electronic device that has a special function to download the latest information with the latest technologies to make life more practical (Indrawan, 2004). The various interesting features created using sophisticated technologies make gadget use is increasing among early childhood. This statement is in line with the research findings by Ismanto and Onibala (2015) who said that the use of gadgets among early childhood has rapidly increased recently.

The increase of gadget use in early childhood gives both positive and negative impacts on the children's mental health, especially those related to their social and emotional development. Study findings by Ismanto and Onibala (2015) show that children who often play gadgets alone will have less chance to interact with other children in their environment. Such a lack of opportunities to interact with others will affect their social and emotional development. Other studies also suggested that the use of digital media has an effect on the ability of children's attention such as increased hyperactivity and difficulty in concentrating and they also feel sad or bored with their friends (Kim, 2013). The consequences are, these gadgets will affect the children's behavior in the class, in which they become difficult to concentrate in learning things taught by the teacher in classes, more hyperactive that they cannot quietly sit while completing a task given, and also feel uncomfortable playing with their friends. Even though, most of the learning in the Early Childhood Education and Development (ECED) involves friends to do activities together in the classrooms. All of those behaviors mentioned beforehand have an impact on the overall mental health of the child.

Come from those arguments, this study aims to find out how the perception of the teacher is about the impact of gadget use on the mental health of early childhood. More specifically, the study objectives are:

1. What is the teachers' perception of the positive impact of gadget use on the mental health of early childhood?

2. What is the teachers' perception of the negative impact of gadget use on the mental health of early childhood?

\section{METHODOLOGY}

The method used by the researcher in this study was descriptive. A descriptive method is a method used to narrate and interpret data related to the facts, variable conditions, and the phenomena that occur during the study and present the data as the way it is (Subana, 2011). This study used a case study approach and took place in an ECED in Pontianak city. This ECED is chosen because some children have problematic behavior, making them less active in the learning activity in the class. From the interview with their parents, that children are used to playing gadgets over time, in which it is considered rare in early childhood students in Pontianak city.
The research used three forms of data collecting techniques, which were: (1) direct observational technique by directly observing the children who have problematic behavior activity, (2) direct communication technique by interviewing the headmaster of the ECED and 7 teachers of A and B classes, and (3) documentary study through teachers' data, students' data.

Location of the research in Pontianak city and conducted within 4 months (in 2019). The population consisted of 1 ECED headmaster with 7 teachers of A and B classes. This study was a case study, and the subject in this study was 1 headmaster of ECED and 7 teachers of A and B classes, also some students who have problematic behavior in the classroom.

Data were analyzed using theory by Spradley. According to Spradley, there are 4 stages in analyzing data, which are: (1) domain analysis, (2) taxonomy, (3) componential, (4) cultural theme (Sugiyono, 2008).

The domain analysis was conducted to obtain a general description of the social situation studied or research object. The domain in this study is the general description of some students who have problematic behavior in the classroom. The taxonomy analysis is the analysis of the whole data obtained based on the determined domain. In this study, the domain is the described data about some students who have problematic behavior in the classroom.

Component analysis in this study was obtained through selected observation, interview, and documentation. In the component analysis, the researcher found more specific data from some students who have problematic behavior in the classroom.

Cultural-themed analysis in this study was obtained through the data analysis guidance above to simplify the description of this study finding and to prove the data validity of this study findings. The data referred to here is the data of observation result, interview result, and documentary study, which were holistically described.

\section{RESULTS AND DISCUSSION}

The study result reveals that all the teachers had the same perceptive that gadget has both positive and negative effects on early childhood's mental health. The positive impact of the gadget for early childhood's mental health is the contains of the games can stimulate the creativity and imagination for the children. Besides, the games in the gadget should be educative so they can learn in a fun way. The positive emotion of children when learning using gadgets will also maintain their mental health.

This result is in line with a study by Patricia \& Don (2008) claimed that in Australia, gadgets are used in the classroom to assist the learning process, in which the quality educational games are developed for preschoolers such as games about forms, colors, numbers, counting, and reading. Besides, the positive impact of gadget use is to facilitate children in sharpening their creativity and intelligence. For example, there are applications to learn coloring, reading, and writing letters which certainly have positive impacts on children's brain development (Novitasari and Khotimah, 
2016). Sinta (2018) mentioned the positive impact of gadgets including (1) improving vision, (2) improving typing skills, (3) reducing stress levels, (4) inducing children's imagination. Thus, it can be concluded that the gadget also has a positive impact on children's development, such as increasing creativity, imagination, and help children to learn colors, numbers, counting, and reading in a fun way.

Moreover, children who have positive emotions, are creative and imaginative, are the characteristics of children with good mental health. According to the previous research, mental health plays a vital role in the development of the social and emotional capacities of a student as well as being a key influential factor in potential academic success. (Askell-Williams, \& Lawson, 2014). Mentally healthy children possess the ability to: (a) develop psychologically, emotionally, socially, intellectually, spiritually, (b) initiate, develop and sustain mutually satisfying interpersonal relationships, (c) use and enjoy solitude, (d) become aware of others and empathize with them, (e) play and learn, (f) develop a sense of right and wrong (Mental Health Foundation, 2002). Children who are mentally healthy also resolve (face) problems and setbacks satisfactorily and learn from them (Alexander, 2002). Therefore, it can be concluded that gadgets have a positive impact on the mental health development of early childhood.

The negative impact of the gadget for early childhood's mental health is if there they become addicted to the gadget so they spend more time playing gadget and refuse to interact with other people. As an effect, they will face difficulty in communicate with other people, get angry easily, hard to concentrate, unruly, which such things may cause deterioration in their mental health.

Many experts have claimed that there are negative impacts of the gadget for early childhood if it's used excessively without parental supervision as well as without clear time use limitation. Moreover, the gadget is only used to play games without educational elements.

A study by Delima, Arianti, and Pramudyawardani (2015) stated that almost all parents $(94 \%)$ said that their children often play using technology tools/gadgets to play games. Children prefer to use their gadgets for playing instead of learning or playing outside with friends their age (Nurrachmawati, 2014).

This argument is in line with the theory by Iswidharmanjaya and Agency (2014) about the negative impact of gadget use in children, which is when they have become addicted; they will act as if the gadget is the part of their lives. This addiction is one of the very significant negative impacts (Prasetyo, 2013).

Novi (2015: 154) stated that the children's habit to spend time playing games will significantly affect their mental. Study findings by Anggrahini (2013) show that since they use gadgets, children are hard to communicate, ignorant, often have a bad mood, and ignore the parent's advice. All those negative impacts caused by gadget use in early childhood indicate that there is deterioration in the children's mental health. Children who have poor mental health will face difficulty in concentrating, thus it will be hard for them to learn and cannot optimally achieve things (Leavers, 2005). Therefore, it can be concluded that gadget use can also harm early childhood mental health.

\section{CONCLUSIONS}

Based on the conducted research, it can be concluded that the teachers stated that gadget use has both positive and negative impacts on early childhood mental health. Specifically, the results of this study's objective were as follows: (1) The positive impact of the gadget for early childhood's mental health is the contains of the games that can stimulate the creativity and imagination for the children. Besides, the games in the gadget should be educative so they can learn in a fun way. The positive emotion of children when learning using gadgets will also maintain their mental health. (2) The negative impact of the gadget for early childhood's mental health is if there they become addicted to the gadget so they spend more time playing gadget and refuse to interact with other people. As an effect, they will face difficulty in communicate with other people, get angry easily, hard to concentrate, unruly, which such things may cause deterioration in their mental health.

Based on the study findings, the author suggests these followings: (1) The teachers have found out that gadget has both positive and negative impacts, however, there is still no guidance on how far the positive impact of the gadget is and how far the negative impact of gadget use is for children. (2) The teachers recommend that a guidebook is made regarding the use of gadgets for children in the school, so they can optimize the use of gadgets without giving a negative impact on children. (3) The teachers realize the importance of maintaining mental health for early childhood and they are expected to optimize the children's learning ability and they can learn in a fun atmosphere. However, the teachers have not had the knowledge and experience on how to maintain the mental health of their students. So the author suggests to the next researcher to make a guidebook about maintaining the mental health of children in the school environment.

\section{REFERENCES}

Alexander, T. (2002). A Bright Future for All: Promoting Mental Health in Education.

Ameliola, N. (2013). Perkembangan Media Informasi dan Teknologi Terhadap Anak dalam Era Globalisasi. [Online] http://icssis.files.wordpress.com/2013/09/2 013-0229. (Accessed on December 26, 2016).

Anggrahini S. A. (2013). Dinamika Komunikasi Keluarga Pengguna Gadget. Skripsi. Universitas Islam Negeri Sunan Kalijaga, Fakultas Ilmu Sosial dan Humaniora, Yogyakarta.

Askell-Williams, H. \& Lawson, M.J. (2014). Relationships between students' mental health and their perspectives of life at school. Health Education, 115, 249-268. doi:10.1108/HE-02-2014-0007

Delima, R., Arianti, N.K., \& Pramudyawardani, B. (2015). Identifikasi Kebutuhan Pengguna Untuk Aplikasi Permainan Edukasi Bagi Anak Usia 4 sampai 6 
Tahun. Jurnal Teknik Informatika dan Sistem Informasi, 1(1).

Hartati, Sofia. (2007). How to Be a Good Teacher and How to be a Good Mother. Jakarta: Enno Media.

Indrawan, Pana. (2014). Pengaruh Gadget terhadap Tumbuh Kembang Psiko Sosial Anak PAUD. [Online]. http://library.binus.ac.id. (Accessed on March 25, 2016).

Ismanto, Y. \& Onibala, F. (2015). Hubungan Penggunaan Gadget Dengan Tingkat Prestasi Siswa di SMA Negeri 9 Manado. E-journal Keperawatan, 3(2).

Iswidharmanjaya, D., \& Agency, B. (2014). Bila Si Kecil Bermain Gadget. Yogyakarta.

Karman. (2013). Riset Penggunaan Media dan Perkembangannya Kini. Jurnal Studi Komunikasi dan Media, 17(1).

Kim, Y. (2013). Young Children in the Digital Age. Las Vegas: University of Nevada Cooperative Extension.

Laili, Uliyatul. (2017). Influence of Gadget on Social Personal of Early Childhood. Proceeding of Surabaya International Health Conference, July 13-14, 2017.

Leavers, F. (2005). Wellbeing and involvement in care settings. A process-oriented self-evaluation. Leuven: Kind \& Gezin and Research Centre for Experiential Education.

Mental Health Foundation (2002). The Mental Health Needs of Young People with Emotional and Behavioural Difficulties. Bright Futures: Working with Vulnerable Young People. London: Mental Health Foundation.

Novi. (2015). Kebiasaan-Kebiasaan Buruk Sehari-Hari. Yogyakarta: FlashBooks.

Novitasari, Wahyu and Khotimah, Nurul. (2016). Dampak Penggunaan Gadget Terhadap Interksi Sosial Anak Usia 5-6 Tahun. Jurnal PAUD Teratai, 5(3), 182186.
Nurrachmawati. (2014). Pengaruh Sistem Operasi Mobile Android pada Anak Usia Dini. Makassar: Universitas Hasanuddin.

Patricia \& Don, E. (2009). Television, Digital Media, and Children's Learning. Melbourne: Wilkinson Publishing.

Prasetyo, E. (2013). Gadget. [Online]. http://epzna.blogspot.com/2013/08/gadget.html. (Accessed on December 27, 2016).

Rahman, U. (2009). Karakteristik Perkembangan Anak Usia Dini. Lentera Pendidikan, 12, 46-57.

Sinta. (2018). Pengaruh Gadget Terhadap Perkembangan Sosial Anak Di Tk Aisyiyah Bustanul Athfal VI. Skripsi. Universitas Tanjungpura. Fakultas Keguruan dan Ilmu Pendidikan.

Subana. (2011). Dasar-Dasar Penelitian Ilmiah. Bandung: Pustaka Setia.

Sugiyono. (2008). Metode Penelitian Pendidikan (Pendekatan Kuantitatif, Kualitatif, dan R\&D). (Cetakan 6). Bandung: CV. Alfabeta.

Widiawati and Sugiman. (2014). Pengaruh Penggunaan Gadget Terhadap Daya Kembang Anak. http://stmikglobal.ac.id/wpcontent/uploads/2014/05 /artikeliis.pdf. (Accessed on December 10, 2016).

Yates, T., Ostrosky, M. M., Cheatham, G. A., Fettig, A. Shaffer, L., \& Santos, R. M. (2008). Research Synthesis on Screening and Assessing SocialEmotional Competence. Retrieved from Center on the Social Emotional Foundations for Early Learning. http://csefel.vanderbit.edu/documents/rs_screening_ assessment.pdf.

Yulia, Trinika. (2015). Pengaruh Penggunaan Gadget Terhadap Perkembangan Psikososial Anak Usia Prasekolah (3-6 Tahun) di Tk Swasta Kristen Immanuel Tahun Ajaran 2014-2015. Skripsi. 